\title{
STRATEGY FOR TREATING NATURAL ENVIRONMENT INTO POETRY (INTERPRETATION OF THE ECOPOETRY)
}

\author{
Muakibatul Hasanah", Nita Widiati, Dewi Ariani, Rizka Amaliah \\ (Universitas Negeri Malang)
}

\begin{tabular}{ll}
\hline A R T I C L E I N F O & A B S T R A C T \\
$\begin{array}{ll}\text { Keyword: } & \text { The concept of eco-poetic develops in line with changes in the perspective and } \\
\text { eco-poetic utilization } & \text { awareness of poets on the environment. The poet's interaction with nature in the } \\
\text { strategies, learning } & \text { creative process inspired the selection of learning strategies and learning to write } \\
\text { resources, writing natural } & \text { poetry. This study aims to develop a strategy to use the natural environment as a } \\
\text { poetry } & \text { source of learning to write poetry. The results of the implementation show that the } \\
& \text { strategy that departs from natural environment observation activities is effective in } \\
& \text { writing natural poetry. }\end{array}$ \\
\hline
\end{tabular}

\section{INTRODUCTIONS}

Rapid growth and development accompanied by rising economic needs have encouraged humans to explore and exploit natural resources, hereinafter referred to as nature. If exploration activities are supported or that are not supported by the government, both have an impact on the disruption of ecosystems or ecological systems. These two natural phenomena lately, at least in the last two decades, appear more often and their appearance does not stand alone as a natural phenomenon but is related to natural exploration activities.

Responding to these conditions, as part of a social institution that is also responsible for environmental sustainability as the antithesis of environmental/ecology damage, literary actors feel called to also fight for or at least voice concern, concern, or protest against acts of environmental destruction in the name of development or welfare and humanity through literary works. The concept of eco-criticism arises as an idea that aims to integrate the contents of the environment into literature. Eco-aesthetic is a form of response to eco-criticism. Eco-criticism is a concept of ecological wisdom that is packaged into literature (Phillips, 1999: 580 - 583).

In the world of poetry or poetry writing the same thing happened, the author began to raise environmental issues in his poetry compositions (Aji, Pratiwi, \& Widiarti, 2018). Specifically, the environmental issues raised in poetry gave rise to ideas about eco-poetic. Eco-poetic emerged as a result of Eco-criticism which was seen as failing in understanding natural poetry. Eco-poetic itself is a practical tool for understanding natural poetry. Eco-poetic is an awareness of the relationship between humans and nature.

In the realm of education (including learning) literature, the concept of eco-poetic can be transformed in the form of inviting students to write poetry about nature, more precisely about environmental sustainability. To make it happen, instead of teaching students, the teacher conditions students to develop their own learning strategies. Premises other words, educators give to the opportunity of the learners to recognize the potential and interest in the natural environment, then process it into poetry.

\footnotetext{
* Corresponding author.

E-mail addresses: muakibatul.hasanah.fs@um.ac.id (Muakibatul Hasanah)
}

ISSN : 2597-7385 (Online) - ISLLAC : Journal of Intensive Studies on Language, Literature, Art, and Culture is licensed under Creative Commons Attribution-ShareAlike 4.0 International License (http://creativecommons.org/licenses/BY/4.0/). 
The way students learn to write poetry can be done by adopting the poet's way of the creative process. The results of previous studies (Hasanah \& Siswanto, 2008) show that the creative process is undertaken by Indonesian poets mostly involves physical and psychological activities to produce quality poetry.

The surrounding environment provides many abundant learning resources for writing poetry. The Malang region as an example provides a selection of the hills, rice fields, rivers, sea, urban and even complete with a problem: sanitation, clean water, and flooding. Malang area surrounded by mountains, showing a hilly face that slowly turns into a residence raises the danger of direct land and flooding. Rice fields slowly turn into dwellings, roads or industrial estates. Rivers in the city that have turned into giant gutters or become waste dumps. The sea which has caused abrasion and sea level rise and damaged coastal areas.

On the other hand, if nature is preserved, it creates a beautiful, charming, and amazing natural environment. Such nature will provide sources of ideas for writing poetry for students - students or students - who intend to process creatively. Natural preparations as a source of ideas for poetry writing will, in turn, create poems with natural, harmonious and reassuring themes for anyone who reads them. In other words, all of that is the potential to be processed as a source of learning to write poetry. Students can easily explore ideas from exposure to the natural environment available around them and then process them into poetry.

If various things related to the surrounding environment are used as learning resources combined with the learning strategies chosen by students, the results can be used as a reference by teachers and lecturers to develop creative writing skills for natural poetry. Rohani (1997) emphasizes its function as a learning resource that facilitates (facilitates) learning activities.

The results of previous studies (Hasanah \& Siswanto, 2011) show that a variety of strategies implemented to students (elementary students) are not entirely successfully implemented. In general, strategies that utilize learning resources in the form of the natural environment is the most successful strategy in the sense of achievement of competence optimizes creative writing poetry as expected. On the other hand, the results of other studies (Hasanah \& Siswanto, 2008) show that the creative process is undertaken by Indonesian poets mostly involves physical and psychological activities to produce quality poetry. Thus, the research on the Utilization of the Natural Environment as a Learning Resource (Interpretation of the Eco-poetic Concept) that combines the two previous research findings to be done.

Generally, this research aims to develop a learner creative writing poetry through the utilization of the natural environment as a learning resource (interpretation of the concept eco-poetic). In particular, this research aims:

(1) produce a draft procedure for learning poetry creative writing through the use of the natural environment as a source of learning,

(2) describe the results of the design test of the applicability of the learning procedure for poetry creative writing through the use of the natural environment as a learning resource, and

(3) document the results of the implementation of learning strategies for poetry creative writing through the use of the natural environment as a source of learning in a collection of naturalthemed poetry books.

\section{METHOD}

In accordance with the purpose of this study carried out in the following two stages. The first stage of the study focused on the development of creative poetry writing learning design through the use of the natural environment as a source of learning and the description of learning activities for poetry creative writing through the use of the natural environment as a source of learning. At this stage, the researchers used a research and development design (Borg \& Gall, 2003 ).

In accordance with the main target drafting phase of the research is the use of models of the natural environment as a source of learning to write poetry, then one step to another step study are as follows. First, a theoretical study is conducted about learning to write poetry. This theoretical study was followed by a study of the results of research related to writing poetry. Second, the drafting of learning to write poetry through the use of the natural environment as a learning resource. Third, do internal validation to get input from the team or experts in the field of writing poetry, the results of which are used to revise the design. Fourth, the field test to determine the learning design implementation 
writes poetry through the use of the natural environment as a learning resource. Fifth, based on the results of field tests, a strategy revision was held. Sixth, dissemination is carried out in the form of scientific article writing to be published in seminar forums and in scientific journals.

The product test in this study in the form of field tests to determine the learning design implementation writes poetry with a usage natural environment as a learning resource. The applicability test is carried out with a descriptive or qualitative research design. The product test design of this study is a qualitative research design on the activities and learning behavior of student poetry creative writing during the implementation test of learning design through the use of the natural environment as a learning resource. In accordance with the research objective, the research data collected is a variety of student behaviors in learning creative writing combined with the results of research related to the utilization of the natural environment as a source of learning.

\section{FINDINGS}

\section{Strategy for Using Nature as a Learning Resource}

In general, strategies designed to utilize nature as a learning resource can be implemented or implemented properly. However, of the six strategies designed, four of them are effective in facilitating students to write poems well. With this strategy, students can explore the idea of observing objects of nature activities. The average of learner able to produce a good poem that best when they are guided by the Worksheet 02, Worksheet 03, Worksheet 05 and Worksheet 06, but they are difficult to produce good poems when they are guided by the Worksheet 01 and Worksheet 04 . The activities are guided by worksheets shall include activities with the following pattern.

(1) Observe-note-responding-writing poetry

(2) Observe-contemplate-elaborate-write poetry

(3) Observe-contemplate cause-respond-write poetry

(4) Observe-contemplate the impact-responding-writing poetry

Activities that are difficult for them to realize are activities with a pattern: (1) imagineprove/observe-respond-write poem, and (2) imagine-prove/observe-compare-write poetry. The following is an explanation of activities with the intended pattern.

\section{(1) Observing-Recording-Responding-Writing}

The stages of natural utilization strategy as a source of learning to write poetry are illustrated in the activity flow in Figure 1.

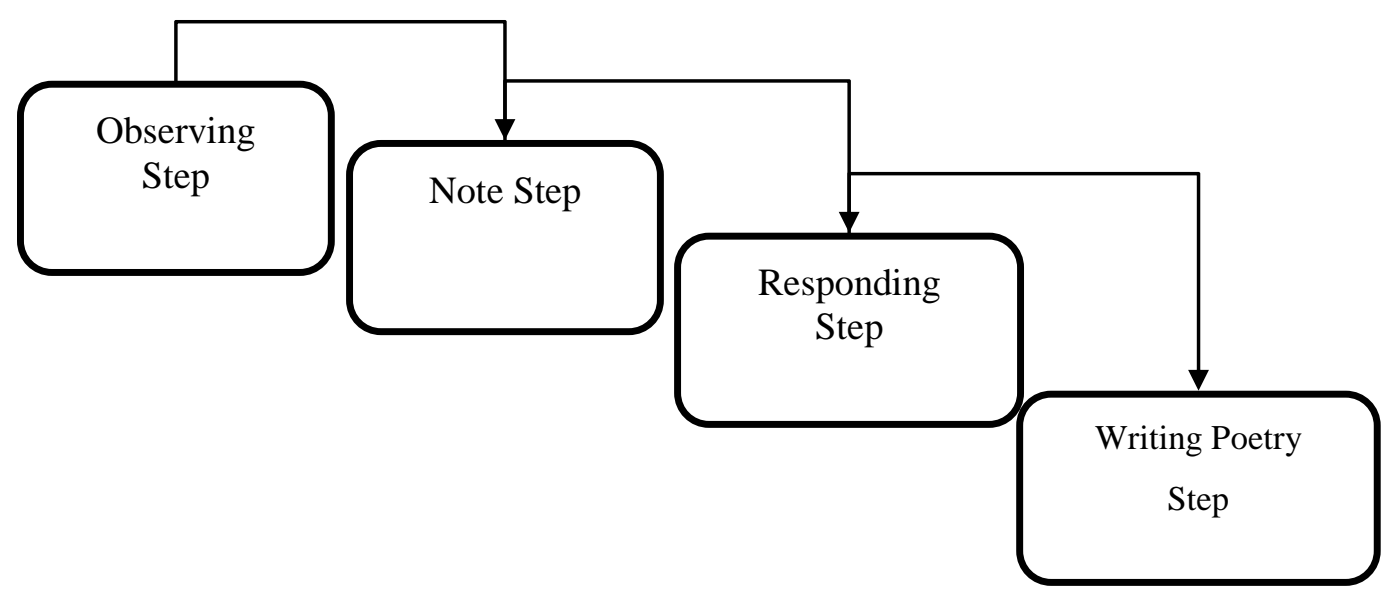

Figure 1 Stages of Learning Activities with Strategy 01 


\section{(2) Observe-Ponder-Elaborate-Writing}

The second stage of natural utilization as a source of learning to write poetry is illustrated in the activity flow in Figure 2.

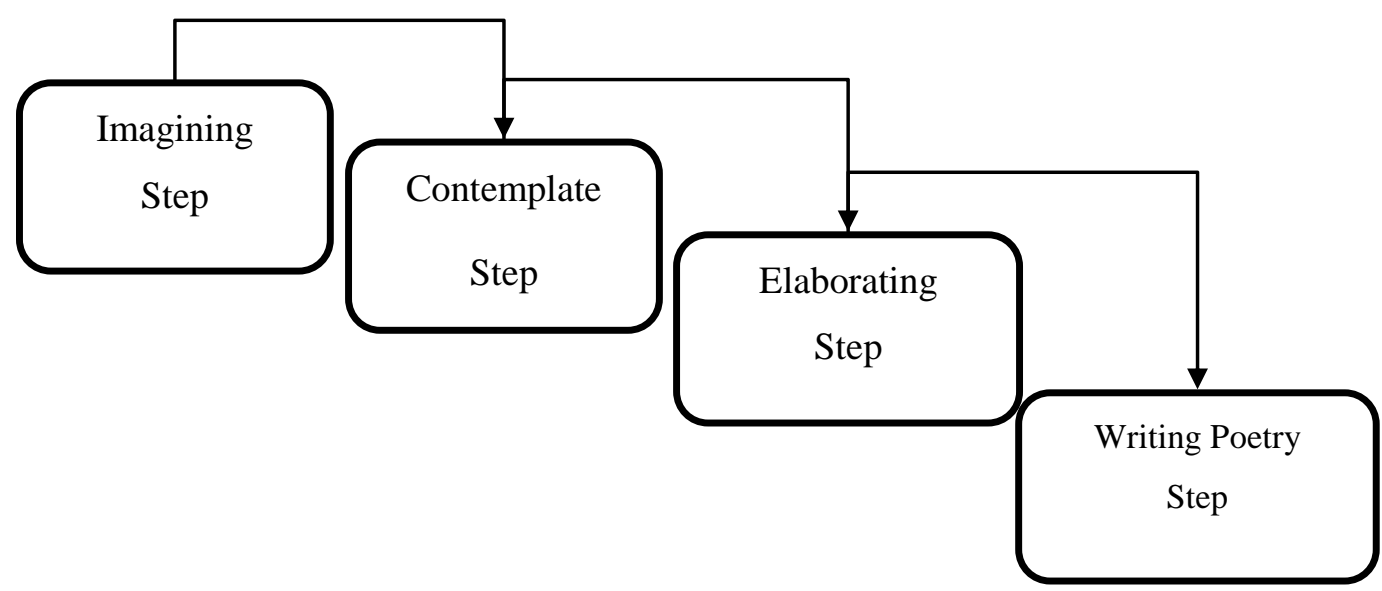

Figure 2 Stages of Learning Activities with Strategy 02

(3) Observing-Contemplating the Cause-Responding-Writing

The third stage of natural utilization as a source of learning to write poetry is illustrated in the activity flow in Figure 3.

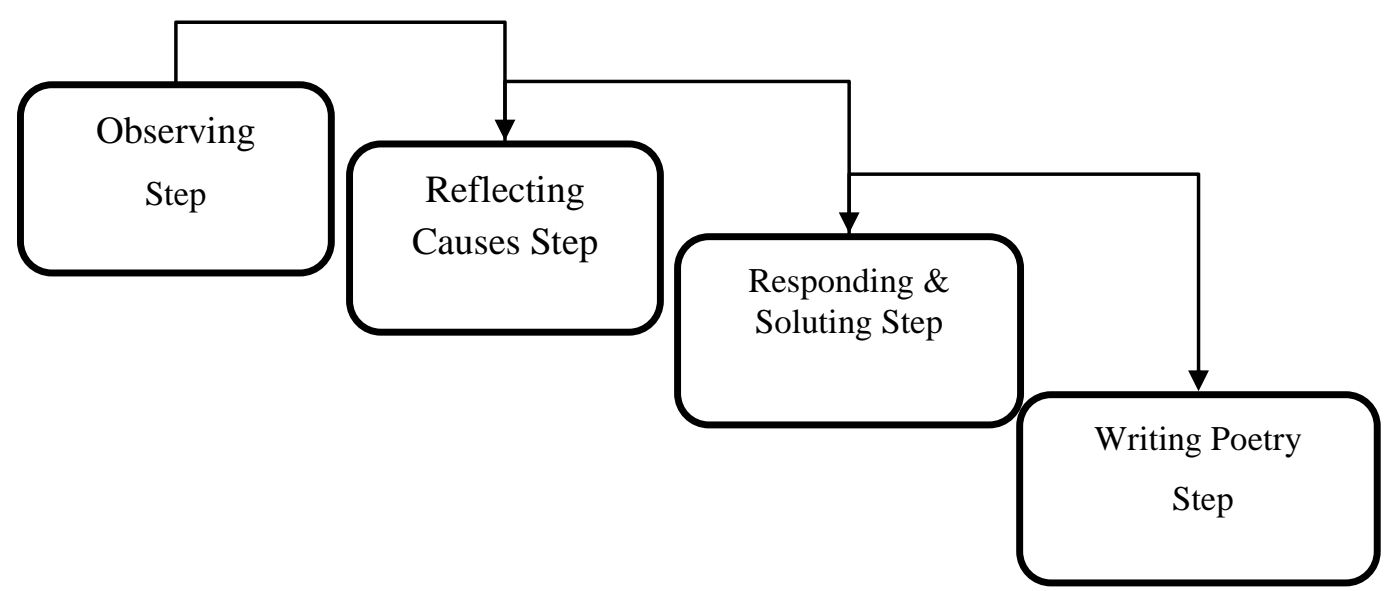

Figure 3 Stages of Learning Activities with Strategy 03

\section{(4) Observing-Thinking of Impact-Responding-Writing}

The fourth stage of the use of natural strategy as a source of learning to write poetry is illustrated in the activity flow in Figure 4.

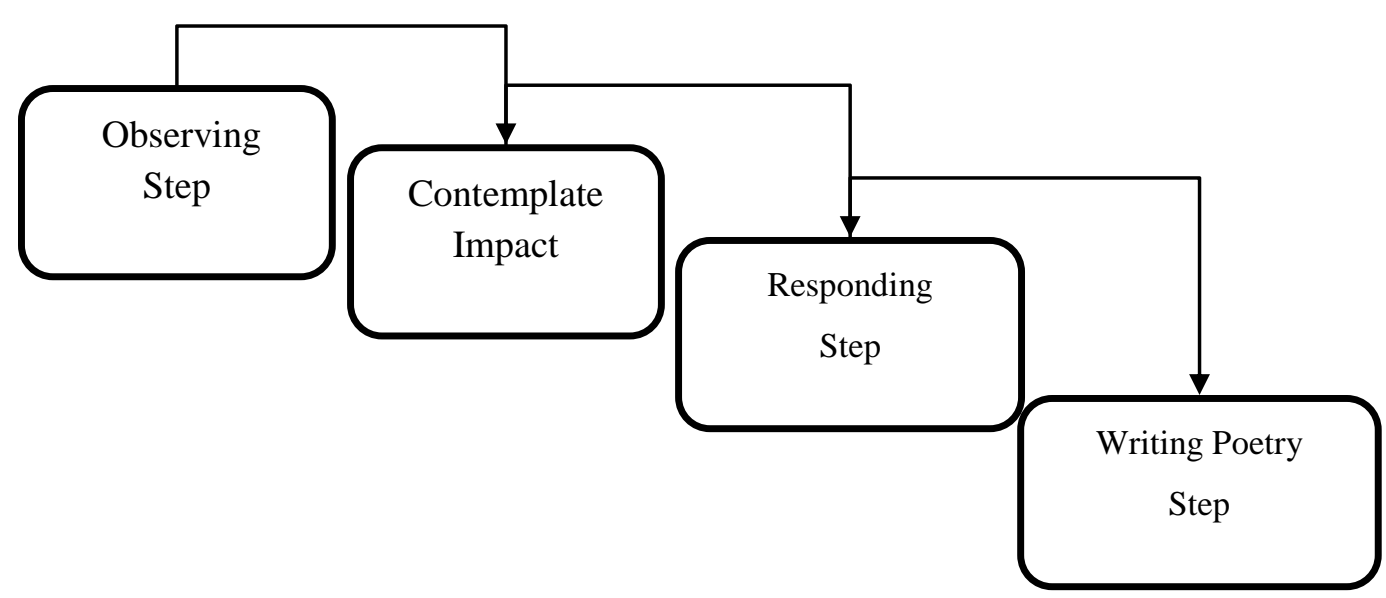

Figure 4 Stages of Learning Activities with Strategy 04

79 | ISLLAC : Journal of Intensive Studies on Language, Literature, Art, and Culture 


\section{(5) Imagining-Observing-Proving-Writing}

The second stage of natural utilization strategy as a source of learning to write poetry is illustrated in the activity flow in Figure 5.

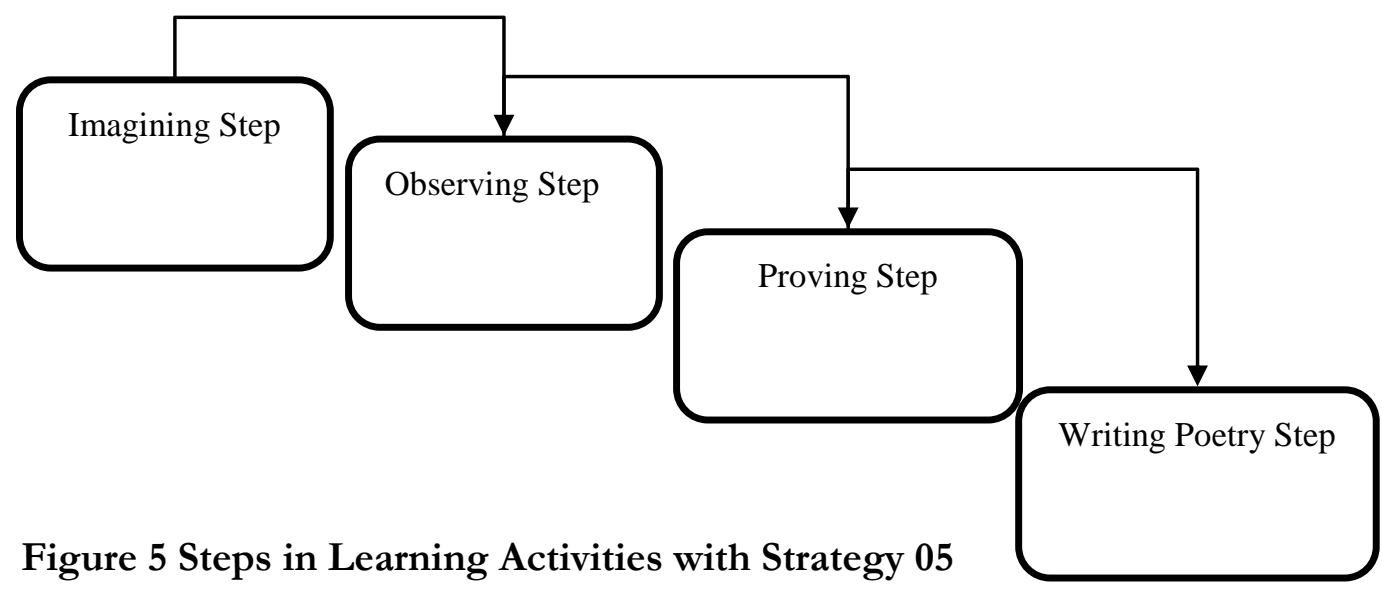

\section{(6) Imagine-Prove/Observe-Respond-Write Poetry}

The sixth stage of strategy for using nature as a source of learning to write poetry is illustrated in the activity flow in Figure 6.

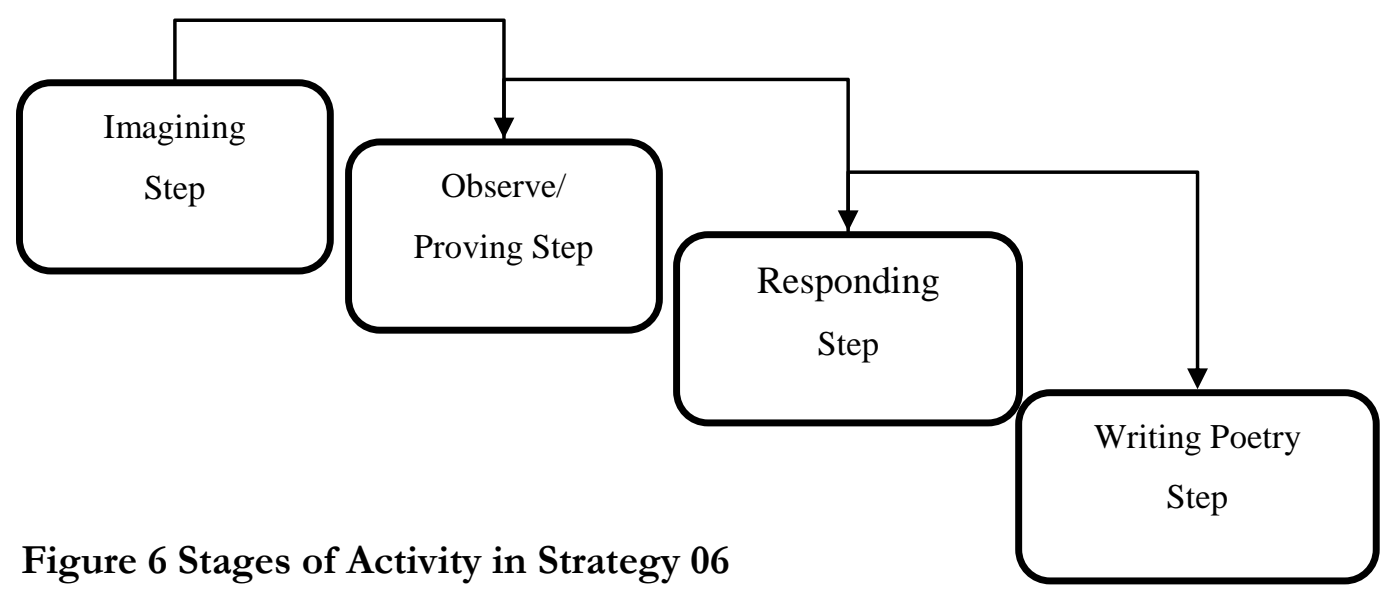

\section{Poetry Results of Strategy Implementation}

Class B students of Language Study Program and Indonesian Literature class of 2015 consisted of 36 students who produced 156 poems produced by students. Poems by students are analyzed by criteria: (a) themed nature, (b) choosing diction related to nature, (c) repetition of the sound, (d) using varied images, (e) creating new assemblies, (f) using means rhetoric, (g) using typography, (h) and forming a unified whole idea of poetry. Data analysis begins with intensive reading and assesses poetry based on established criteria. Furthermore, the poem is divided into poems that are in accordance with the criteria and poetry that do not fit the criteria.

Data in the form of poetry product156 student works derived from activities observation two objects that region Amarta Hills Stone Hotel and natural attractions region Rais Falls. Based on the results of poetry analysis, there were 108 poems that were in accordance with the criteria for writing natural poetry and a number of 48 poems that do not fit the criteria.

Natural poetry produced by students from activities using nature as a learning resource for writing poetry shows the following findings.

(1) The treat idea has been done by the students. This can be seen from the quality of wholeness and the development of ideas in the poetry they produce.

(2) The choice of words in poetry made by students has varied with reference to nature as the object of observation.

(3) The use of images in the poems produced by students has been good and varied. 
(4) The use of figure language has varied, both direct and indirect comparisons.

(5) The user of the means of rhetoric varies in the form of repetition, deviation in form, patterned form, and word abbreviations.

(6) The repetition of sound in student poetry has been arranged both loopings in one array, or between lines.

(7) The poetry produced by students has paid attention to typography in the form of array and temple arrangement so that it creates a unique, distinctive and new form, there is also a balance in array and temple arrangement.

\section{DISCUSSIONS}

Writing is heavy duty and needs control attention, self-monitoring, and control will (Schunk, 2008). By because that, is needed a strategy appropriate to learning and able to improve thirdtype control that is. Interaction directly with nature offset with procedure activity prewriting, writing, and up improvement poetry is effort realize it enhancement third control that is

The strategy which was developed through a pattern of activity usage nature as a source of learning have characteristics based on physical activities and non-physical (psychological) activities. The activities that are based on physical activities such as walking, observing conditions, visiting locations that are related to nature, and interacting with nature. Activities that are based on psychological activities related to mental processes such as predicting, imagining, supposing, projecting, elaborating, and contemplating events related to nature.

Six strategies with the intended characteristics are designed and implemented for students participating in the Poetry Writing course. The results of the implementation show that four of the strategies are designed to be effective in facilitating students to write poems well. With this strategy, students can explore the idea of observing objects of nature activities and students average able to produce a poetry that bags us. Two of the strategies designed have proven to be less effective.

The four strategies in question include Strategy 01: observing notes-responding-writing poetry; Strategy 02: Observes-pondering-elaborating-writing poetry; Strategy 03: Observe - reflect on the cause-respond-write poetry; Strategy 04: Observe-contemplate the impact-responding-writing poetry. The four strategies have general characteristics, namely starting with observing activities.

Characteristics that is could compared with opinion of Spiro

(2008:9) that strategy commonly used learners in process creative write poetry among others: adopting rul es happiness and use it in works written; looking for vocabulary necessary and when not find it, they will do replacement vocabulary with synonym or construction a new word; and transfer sound, rhythm, and pattern language into language target used in writing poetry. The general strategy that is on basically contains activity observe, compare, and ponder vocabulary and aspect other language for creating works.

Strategy results development leave from observation directly related fill in or idea writing, temporary strategy general related to Spiro with form the language that wraps fill in. Strategy results development facilitate learners for dig and process ideas, whereas strategy general facilitating Spiro's processing means poetic decisive is something creation worthy called poetry. Both cold utilized by a lecturer in learning write poetry because each other complete.

Four strategies implemented and produce out in the form of quality work, in fact, is a development from the third strategy - which is true has been doing by the author in a manner naturalthat. Effort explores potency language on each college student do with approach ecocriticism which is expansion natural internal strategies that they have it.

This finding can be understood because observing is a concrete activity that is easier for someone to do. Observing students can directly perceive natural objects through the five senses. Students can also interact directly with nature, and mental processes are more easily realized.

By observing natural objects, students can directly perceive nature through the five senses that function optimally in various ways. With the smell of kissing, students can breathe clean air, smell the smell of leaves exposed to dew or the smell of wet soil. With the senses of seeing students can look at towering trees, rivers that flow clear water, waterfalls down the cliffs, or colorful flowers that grow wilds. 
With the senses of listening, students can listen to birdsong, gurgling river water, or the sound of swift waterfalls, or the rustling of leaves. With the sense of touch, students can feel the heat of cold air, splashes of water on the skin, soft flower petals, or grains of dust or sand attached to the skin. With the sense of taste, students can feel the fresh clear water, the sweetness of the flower juice, or the bitterness of oxygenrich water.

Through observation, students can interact directly with nature freely. Students can set foot barefoot on grass and rocks. Students can touch cold water flowing between stones directly. Students can also stroke the leaves or soft flower petals. Students can wash their faces and feet under a heavy waterfall. Students can feel soft gusts of wind that hit their faces and hair on their heads or gusts of wind that blow hats and umbrellas.

These experiences make it easier for students to carry out more complex mental processes. Students are easier to think of natural objects that are clearly displayed in front of them, processing them into products that think and feel creatively. Students find it easier to reflect on what has happened and will happen to nature, and students find it easier to find solutions to all problems related to natural phenomena.

The interaction between college student with natural in a manner directly become an emotional stimulus that can direct learning on effort contemplation in a manner deep to objects were observe. According to Schunk (2012:83) stages, certain will trigger different emotions between one person with others person. Stages complex learningespecially in writing creative poetry--will netting so that possibilities essence a poetry will

be very rich emotion. Process contemplation based on observation will direct happened.

The opposite does not necessarily apply to two of the strategies that have proven to be less effective. That is, the two strategies in question are not functioning at all. In some students, both strategies are quite effective in facilitating students to write natural poetry (Check the exposure to the results of the implementation of Strategies 05 and 06). The two strategies in question have general characteristics, namely starting with imagining activities. In contrast to more concrete observing activities, imagining activities are more imaginative. To be able to do it, one must have a number of requirements, including being able to imagine, having experience with objects imaginable, being able to bring back experience, and having sufficient knowledge about objects.

Involvement emotion and mind in write poetry natural strengthen opinion Dewi (2015) that write creation literature is processed hone sense mind and feeling with way empathize on various experience life humans. This to

show that interaction concrete with object environment natural in poetry could enrich ability imagination and strengthen depth substance idea in poetry the resulting because involving feeling and empathy in the form of results experience self-contemplation.

The difference in the results of the implementation tends to be on the quality of the results of the implementation of the strategy. Effective and less effective strategies are both useful for students in using nature as a learning resource. Various advantages are available in nature as a learning resource. Nature is an original learning resource that is abundant around students. Nature also stores a variety of potential biological and non-biological sources as learning resources. Nature is also challenging for students to come, interact and process it as a source of writing. In the end, nature serves as a provider of issues that invite students to appear as problem solvers. In its description students try to express their experiences when interacting with nature as the object of observation. These expressions include concerns about damage to the earth, resistance to exploitation practices that damage the earth, or rejection of behavior that is not pro-nature. Eco-poetic consists of three categories, namely a strong emphasis on nature, an emphasis on the need to maintain natural harmony and its aspects, and focus on the emergence of hyperrationality and over-technology that damages ecology (compare with Glotfelty, 1996; Love, 2003:38; Gerrard, 2004: 2.)

Results writing poetry by a

student who indicated attention to natural and effort keep harmony natural and its aspects referring to on approach perspective ethical. This in line with idea Sukmawan (2016)about essence study literature ecocriticism perspectives ethical focused on payload (1) respect to nature, (2) attitude bear it answer to nature, (3) attitude solidarity to nature, (4) attitude love Dear and caring, and (5) attitude not disturb balance nature . 
Related to the issue, natural poetry produced by students from strategy implementation consists of three slightly different categories, namely strong attention to nature, emphasis on the need to maintain natural harmony and its aspects, and concentration on the emergence of symptoms of land use damage that damage the ecology. The different categories are caused by the characteristics of natural objects that are used as a source of learning to write poetry.

\section{CONCLUSIONS}

Based on the results of the study it can be concluded that the use of nature as a source of learning to write poetry can be done with various learning strategies. Of the six learning strategies that are designed, four strategies are well implemented so as to produce beautiful natural poetry. The strategy involved includes strategies with patterns: (1) observing-responding-writing poetry, (2) observingpondering-elaborating-writing poetry, (3) observing-reflecting on the cause-respond-writing poetry, (4) observed-contemplating the impact of response-writing poetry. The other two strategies are not optimal in facilitating learning to write natural poetry, even though it does not mean that it does not function at all, namely a strategy with a pattern (1) imagining-proving/observing-responding-writing poetry, and (2) imagining/observe-compare-write poetry.

Natural poetry produced by students from activities using nature as a source of learning to write poetry is divided into poems that meet the criteria for the means of poetry and poetry that do not meet the criteria. Most poems (108 out of 156 poems) by students meet the criteria: (a) themed nature, (b) choose diction related to nature, (c) repetition of the sound, (d) use varied imagery, (e) create majors new, (f) using the means of rhetoric, $(\mathrm{g})$ using typography, and $(\mathrm{h})$ forming a unified whole idea of poetry.

Based on the conclusion, the following suggestions can be given. To the coaches of the Poetry Writing course, it is recommended to use various strategies for using nature as a source of learning to write poetry. Planning and use of strategies will make it easier for students to learn to write poetry and be more productive in producing poetry, especially natural-themed poems. In addition, after getting written ideas students also need to get guidance from the lecturer to develop ideas and organize their poetry so that poetry that is worth mentioning is produced.

\section{REFERENCES}

Aji, G. P., Pratiwi, Y., \& Widiarti, N. (2018). DEVELOPMENT OF INSTRUCTIONAL MATERIALS WRITING POETRY BASED ON NATURE TOURISM FOR POETRY LEARNING. ISLLAC: Journal of Intensive Studies on Language, Literature, Art, and Culture, 2(1), 35-39. Borg \& Gall. (2003). Education Research. New York: Allyn and Bacon.

Dewi, N. (2015). Manusia dan Lingkungan dalam Cerpen Indonesia Kontemporer: Hasil Analisis Ekokritik Cerpen Piliban Kompas. (Online), retrieved from (https://journal.uny.ac.id/index.php/litera/article/viewFile/7211/6216), 27 Oktober 2018

Gerrard, G. (2004). Ecocriticism: The New Critical Idiom. New York: Routledge.

Glotfelty, C dan Fromm, H. (1996). The Ecocriticism Reader: Landmark in Literary Ecology. Athens: The University of Georgia Press.

Hasanah, M. dan Siswanto, W. (2008). Proses Kreatif Sastrawan Indonesia. Malang: Lemlit UM.

Hasanah, M. dan Siswanto, W. (2011). Pengembangan Buku Teks Pembelajaran Menulis Puisi Berbasis Kebutuban dan Perkembangan Siswa. Malang: Lemlit UM.

Love, G. A. (2003). Practical Ecocriticism: Literature, Biology, and Environment. Charlottesville: University of Virginia Press.

Phillips, D. (1999). Ecocriticism, Literary Theory, and The Truth of Ecology. New Literary History. 1999. 30:577-602. The Johns Hopkins University Press

Rohani, A. (1997). Media Instruksional Edukatif. Jakarta: Rineka Cipta.

Schunk, D. H. (2012). Learning The Theories: An Educational Perspective. Yogyakarta: Pustaka Pelajar.

Spiro, J. (2008). Creative Poetry Writing. Oxford: Oxford University Press.

Sukmawan, S. (2016). Model-model Kajian Ekokritik Sastra. (Online), retrieved from (http://fib.ub.ac.id/wrpcon/uploads/1-MODEL-KAJIAN-KEARIFAN-LINGKUNGAN-DALAM-SASTRA.pdf) 28 Oktober 2018.

83 ISLLAC : Journal of Intensive Studies on Language, Literature, Art, and Culture 